\title{
Effect of xylitol on the functional properties of low-fat process cheese
}

\author{
A. Kommineni, J. Amamcharla, and L. E. Metzger ${ }^{1}$ \\ Midwest Dairy Foods Research Center, Dairy Science Department, South Dakota State University, Brookings 57007-0647
}

\begin{abstract}
Process cheese (PC) is a dairy food prepared by blending natural cheese, salt, emulsifying salts, and other dairy and nondairy ingredients, and heating with continuous agitation to produce a homogeneous product. Fat is a critical component of PC and plays an important role in its functional characteristics. The health concerns associated with fat consumption have led to an increase in the demand for low-fat dairy products. Reducing the fat content of PC results in poor functional properties such as increased hardness and reduced melt characteristics. The objective of the current study was to evaluate the effect of xylitol on the functional properties of low-fat PC. Three different low-fat PC formulations were prepared with $0 \%$ (control), $2 \%$, and $4 \%$ xylitol. All 3 PC formulations were formulated to contain $5 \%$ fat, and each treatment was manufactured in triplicate. Rheological characteristics including elastic modulus, viscous modulus, and temperature at Tan $\delta=1$ (melt temperature) were determined using dynamic stress rheometry (DSR). The DSR was carried out at a frequency of $1.5 \mathrm{~Hz}$ and stress levels of $400 \mathrm{~Pa}$, using a temperature sweep from 20 to $90^{\circ} \mathrm{C}$. The hardness of the samples was determined by using texture profile analysis (TPA). Compositional analysis indicated that all treatments had similar fat, protein, and moisture contents. Elastic and viscous moduli results obtained with DSR showed a significant difference between $0 \%$ xylitol (control) and xylitol-containing treatments in the temperature range of 30 to $80^{\circ} \mathrm{C}$. The melt temperature was not significantly different between the 3 treatments. However, TPA demonstrated that the addition of xylitol significantly decreased the hardness of low-fat PC. Based on TPA and DSR data obtained in this study, we determined that xylitol addition improved the functional properties of low-fat PC.
\end{abstract}

Key words: process cheese, low fat, xylitol

Received January 24, 2012.

Accepted June 29, 2012

${ }^{1}$ Corresponding author: Lloyd.Metzger@sdstate.edu

\section{INTRODUCTION}

Process cheese (PC) is a dairy food prepared by blending natural cheese, sodium chloride, emulsifying salts, and other dairy and nondairy ingredients, and then heating with continuous agitation to produce a pasteurized product that is homogeneous and has an extended shelf life (Meyer, 1973; Thomas, 1973; Kapoor and Metzger, 2008). Process cheese or process cheese products utilize nearly one-third of all natural cheese produced in the United States. Process cheese is one of the leading varieties of cheese in the world and is used as an ingredient in various food preparations (Sorensen, 2001; Kapoor and Metzger, 2008). Process cheese is manufactured in a variety of forms such as slices, loaves, shreds, and spreads.

In the United States, the Code of Federal Regulations (CFR) legally defines 3 categories of PC based on the requirements for minimum fat content, maximum moisture content, and minimum $\mathrm{pH}$, as well as the quantity and number of optional ingredients that can be used (FDA, 2008a; 21CFR133.169 to 133.180). A full-fat PC must contain a minimum of $30 \%$ butter fat. This substantial quantity of fat plays an important role in its melting characteristics (Subramanian et al., 2006). Even though fat plays a critical role in the overall acceptability of food products, consumer desire low-fat products due to the association of excess fat intake with heart disease and obesity. Cheese is one of the major contributors of dietary fat in America. Hence, efforts have been made to reduce the fat content in natural and process cheeses (Drake et al., 1999).

According to the CFR, the fat content in a reducedfat PC should be at least 25\% less (FDA, 2008b; 21CFR130.10) than that of its conventional counterpart (that contains a minimum of $30 \%$ fat). To achieve the claim of a low-fat PC, the fat content in low-fat PC must be less than $6 \mathrm{~g} / 100 \mathrm{~g}$ of PC (FDA, 2008c; 21CFR101.62). Consequently, to meet the low-fat requirement, an $80 \%$ reduction in fat relative to full-fat $\mathrm{PC}$ is required.

Manufacture of reduced- or low-fat PC is a challenge to the dairy industry because acceptance of the PC largely depends on its functional properties, in which fat content is a critical component. In natural cheese, 
the fat and moisture are entrapped in a 3-dimensional protein network (Prentice, 1987), which gives structure to the cheese. However, in the manufacture of PC, the use of emulsifying salt, heat, and vigorous mixing result in a stabilized emulsion of fat within the protein matrix (Lee et al., 2003; Price, 2007). This phenomenon gives a unique microstructure to $\mathrm{PC}$, which consists of a protein network containing an evenly dispersed fat phase that gives $\mathrm{PC}$ its functional characteristics (Kapoor and Metzger, 2008; Johnson et al., 2009). Within the protein matrix, fat plays an important role in cheese texture by providing lubrication (Raval and Mistry, 1999). Consequently, when the fat content of $\mathrm{PC}$ is reduced, an increase in the protein network and a decrease in lubrication provided by fat occur, which results in a firm, rubbery texture and poor melting characteristics (McMahon et al., 1996; Zhong, 2003).

Most of the fat in PC is derived from the natural cheese used in its manufacture (Johnson et al., 2009). Hence, utilization of fat-free or nonfat natural cheese lowers the fat content in PC. However, lower fat or nonfat natural cheese is associated with many functional and organoleptic defects, which tend to be carried over into the PC (Muir et al., 1997; Gwartney et al., 2002). The fat in PC can be replaced by adding water, protein, or other additives such as gums and stabilizers (Caric and Kalab, 1993; Lee et al., 2003). The acceptability of low-fat PC can be improved by using fat replacers that partially or fully replace fat and simulate the properties of fat (Jones, 1996; Drake et al., 1999).

Fat replacers are classified according to the substances from which they are derived. Carbohydrate-based fat replacers include pectin, gums, starch, dextrin, vegetable fibers, and carrageenan. Protein-based fat replacers include modified whey protein and soy protein. Lipid-based fat replacers include mono- and diglycerides, olestra, salatrim, and carpenin (Napier, 1997).

Several different fat replacers have been shown to produce reduced-fat $\mathrm{PC}$ with improved functional characteristics (Davison and Schwimmer, 1993; Mehnert and Prince, 1996; Drake et al., 1999; Swenson et al., 2000). A study on the physical and sensory properties of reduced-fat PC spread made using hydrocolloid fat mimetics concluded that the texture of $40 \%$ reduced-fat $\mathrm{PC}$ was comparable to that of full-fat PC (Brummel and Lee, 1990). Drake et al. (1999) reported that 50\% reduced-fat PC containing lecithin had improved functional properties (elasticity, firmness, and cohesiveness) relative to a $50 \%$ reduced-fat control that contained no lecithin. Hassan et al. (2007) reported that 35\% reduced-fat PC produced with reduced-fat Cheddar made from exopolysaccharide (EPS)-producing starter cultures had a softer texture compared with a $35 \%$ re- duced-fat PC control that contained no Cheddar made from EPS-producing starter cultures. All of these studies indicate that the functional properties of $\mathrm{PC}$ with up to $50 \%$ reduced fat can be improved with the use of fat replacers. However, no study has been conducted to evaluate the functional properties of low-fat $(\leq 6 \%$ fat) PC.

Xylitol is a carbohydrate-based, hydrocolloid fat mimetic substance that has not yet been evaluated as a fat replacer in reduced- or low-fat PC. Xylitol is a Food and Drug Administration-approved sugar alcohol that can be used in foods as an ingredient. Xylitol is an intermediate product of carbohydrate metabolism obtained from xylan-containing plant materials (Sandrou and Arvanitoyannis, 2000). Xylitol has also attracted the interest of food scientists for use as a sugar replacer because of its sweetening power and low caloric property. Xylitol is highly hygroscopic in nature and absorbs water in foods (Tomasik, 2003; Mushtaq et al., 2010). The hygroscopic nature of xylitol results in formation of a gel-type texture that provides lubricity, which may improve the texture of low-fat PC. Previous studies on low-fat cookies with added xylitol (Zoulias and Piknis, 2000) have shown improved functional properties. Because the use of xylitol has not been evaluated in low-fat PC, the objective of the current study was to determine the effect of xylitol on the functional properties of low-fat PC.

\section{MATERIALS AND METHODS}

\section{Process Cheese Formulations}

Three different PC formulations were developed that contained $0 \%$ xylitol (control), $2 \%$ xylitol, and $4 \%$ xylitol. The ingredients used in each formulation are shown in Table 1 . The ingredients used were trisodium citrate (KIC Chemical Inc., New Paltz, NY), salt (Cargill, Minneapolis, MN), fat-free Cheddar (Valley Queen Cheese Factory, Milbank, SD), aged Cheddar (Cabot Extra Sharp Cheddar, Cabot, VT), 88\% lactic acid (Fisher Scientific, Pittsburgh, PA), sorbic acid (Hawkins Inc., Minneapolis, MN), lactose (Fisher Scientific, Pittsburgh, PA), xylitol (Danisco USA Inc., Thomson, IL) and water. The same blend of fat-free and aged Cheddar cheeses was used for all the treatments and replicates. The primary carbohydrate in PC is lactose and a typical PC formulation will have approximately $4 \%$ lactose. In PC, lactose is used as filler and has a minimal effect on the functionality (Kapoor and Metzger, 2008). Consequently, to balance the composition of each formulation, addition of xylitol was compensated by a reduction in lactose: the $0 \%$ xylitol 
Table 1. Formulation of process cheeses made with addition of 0,2 , or $4 \%$ xylitol

\begin{tabular}{lrrr}
\hline & \multicolumn{3}{c}{ Xylitol } \\
\cline { 2 - 4 } & $0 \%$ & & \\
Ingredient & $($ Control $)$ & $2 \%$ & \multicolumn{1}{c}{$4 \%$} \\
\hline Aged Cheddar cheese (\%) & 12.00 & 12.00 & 12.00 \\
Trisodium citrate (\%) & 3.00 & 3.00 & 3.00 \\
Salt (\%) & 0.70 & 0.70 & 0.70 \\
Water (\%) & 17.24 & 17.24 & 17.24 \\
Lactic acid (\%) & 0.40 & 0.40 & 0.40 \\
Sorbic acid (\%) & 0.20 & 0.20 & 0.20 \\
Fat-free cheese (\%) & 62.46 & 62.46 & 62.46 \\
Lactose (\%) & 4.00 & 2.00 & 0.00 \\
Xylitol (\%) & 0.00 & 2.00 & 4.00 \\
\hline
\end{tabular}

(control) formulation had $4 \%$ lactose, the $2 \%$ xylitol treatment had $2 \%$ lactose, and the $4 \%$ xylitol treatment had no lactose. The sweetness of xylitol is similar to that of sucrose and, at the $2 \%$ and $4 \%$ addition levels used in this study, it did not affect the flavor of the PC. An Excel-based software program called Tech Wizard (Metzger, 2003) developed by Owl Software (Lancaster, PA) was used for developing all 3 formulations, which contained $55 \%$ moisture, $5 \%$ fat, and $27 \%$ protein.

\section{Process Cheese Manufacture}

The $3 \mathrm{PC}$ treatments were manufactured in triplicate in 4.5-kg batches using a twin-screw process cooker blender (Blentech Corp., Rohnert Park, CA). During manufacture, all the ingredients were added to the Blentech twin-screw cooker and mixed at $50 \mathrm{rpm}$ for $30 \mathrm{~min}$ at $20^{\circ} \mathrm{C}$ to achieve a homogeneous paste. Subsequently, the temperature of the preblend was increased to $80^{\circ} \mathrm{C}$ over approximately $5 \mathrm{~min}$ and held for an additional $5 \mathrm{~min}$. Auger speed throughout the heating and holding stages was $140 \mathrm{rpm}$. Process cheese was packaged into $1-\mathrm{kg}$ loaves and stored at $4^{\circ} \mathrm{C}$ until analysis was completed.

\section{Chemical Analysis}

Samples were analyzed for fat using the Mojonnier method (Atherton and Newlander, 1977), moisture con- tent using a forced-draft oven (model OV-490A-2; Blue $\mathrm{M}$, Blue Island, IL), and $\mathrm{pH}$ using a Corning $\mathrm{pH} /$ ion meter model 450 (Corning Glass Works, Medfield, MA) fitted with a Thermo Orion combination $\mathrm{pH}$ probe (Thermo Electron Corp., Louisville, CO). All of the analyses on each sample were performed in duplicate.

\section{Analysis of Functional Properties}

Texture Profile Analysis. Hardness of the samples was determined by texture profile analysis (TPA). Process cheese samples were cut into cylinders $20 \mathrm{~mm}$ in diameter and $20 \mathrm{~mm}$ high using a cork borer and cheese slicer. Cheese cylinders were wrapped in Reynolds food service film (Nogg Chemical and Paper, Omaha, NE) to prevent moisture loss and tempered at $20^{\circ} \mathrm{C}$ for at least $1 \mathrm{~h}$ before testing. The TPA was performed using a TA.XT2 Texture Analyzer (Texture Technologies Corp., Scarsdale, NY/Stable Microsystems, Godalming, UK) as described by Drake et al. (1999). Test conditions were as follows: uniaxial 2 bite compression with 50-mm-diameter cylindrical flat probe (TA-25). Three replicates of each sample were analyzed with a crosshead speed of $0.8 \mathrm{~mm} / \mathrm{s}$, and the peak force (cheese hardness) was recorded at $80 \%$ compression.

Dynamic Rheological Analysis. Dynamic rheological analysis was done using a rheometer (ATS Rheosystems, Rheologica Instruments Inc., Bordentown, NJ). Samples were cut into cylinders $28 \mathrm{~mm}$ in diameter and $2 \mathrm{~mm}$ high using a cork borer and cheese slicer. The samples were wrapped in Reynolds food service film (Nogg Chemical and Paper) and stored at $4^{\circ} \mathrm{C}$. To maintain the initial sample temperature at $20^{\circ} \mathrm{C}$, samples were tempered at $20^{\circ} \mathrm{C}$ for at least $1 \mathrm{~h}$ and tested with the rheometer using the parallel plate method. Fine sandpaper (400 grit, 3M, St. Paul, MN) was glued to the upper plate to prevent sample slippage. The sample was placed on the bottom plate and the top plate was brought in contact with the sample. The gap was set at $2.0 \mathrm{~mm}$. Initially, stress sweep and frequency sweep tests were done to determine the linear region that was required to conduct the temperature sweep. The dynamic rheology test was conducted using a temperature sweep at a frequency of $1.5 \mathrm{~Hz}$ and

Table 2. Mean squares ( $P$-values in parentheses) of chemical properties of process cheese

\begin{tabular}{lccccc}
\hline Factor & df & $\mathrm{pH}$ & Moisture & Fat & Protein \\
\hline Replicate & 2 & 0.00100 & 0.09400 & 0.00003 & 0.04500 \\
& & $(0.45)$ & $(0.56)$ & $(0.99)$ & $(0.58)$ \\
Treatment & 2 & 0.00300 & 1.28700 & 0.00243 & 0.06600 \\
& & $(0.13)$ & $(0.03)$ & $(0.68)$ & $(0.47)$ \\
Error & 4 & 0.00100 & 0.14000 & 0.00596 & 0.07300 \\
\hline
\end{tabular}


Table 3. Mean composition of process cheeses made with addition of 0,2 , or $4 \%$ xylitol

\begin{tabular}{lccc}
\hline & \multicolumn{3}{c}{ Xylitol } \\
\cline { 2 - 4 } Chemical & $0 \%$ & & \\
attribute & $($ Control $)$ & $2 \%$ & $5 \%$ \\
\hline $\mathrm{pH}$ & $5.12^{\mathrm{a}}$ & $5.18^{\mathrm{a}}$ & $5.17^{\mathrm{a}}$ \\
Moisture (\%) & $54.64^{\mathrm{a}}$ & $54.32^{\mathrm{ab}}$ & $53.38^{\mathrm{b}}$ \\
Fat $(\%)$ & $5.08^{\mathrm{a}}$ & $5.02^{\mathrm{a}}$ & $5.06^{\mathrm{a}}$ \\
Protein (\%) & $27.26^{\mathrm{a}}$ & $27.28^{\mathrm{a}}$ & $27.53^{\mathrm{a}}$ \\
\hline a,b Means within a row not sharing a common superscript are signifi- \\
cantly different $(P<0.05)$.
\end{tabular}

at constant stress of $450 \mathrm{~Pa}$ while increasing the temperature at the rate of $1^{\circ} \mathrm{C} / \mathrm{min}$ from 20 to $90^{\circ} \mathrm{C}$. The exposed cheese surface was coated with vegetable oil (ConAgra Foods Inc., Omaha, NE) to minimize drying during measurement. All measurements were performed in triplicate. Data were collected and analyzed as described by Sutheerawattananonda and Bastian (1998). Elastic modulus $\left(\mathbf{G}^{\prime}\right)$, viscous modulus $\left(\mathbf{G}^{\prime \prime}\right)$, tangent angle $(\tan \delta)$, and melt temperature were determined. The melt temperature was defined as the lowest temperature during the temperature gradient experiment, where $\tan \delta$ equaled $1\left(\mathrm{G}^{\prime}=\mathrm{G}^{\prime \prime}\right)$.

\section{Statistical Analysis}

Statistical analysis was performed to study the effect of xylitol on the functional properties of low-fat PC. An ANOVA was performed to obtain the mean squares (MS) and $P$-values using the GLM procedure available in SAS (SAS OnlineDoc, Version 8, SAS Institute Inc., Cary, NC). When a significant treatment effect $(P<$ 0.05 ) was detected, differences among treatment means were tested using the Tukey multiple comparison test.

\section{RESULTS AND DISCUSSION}

\section{Composition}

The ANOVA with MS and $P$-values for $\mathrm{pH}$, moisture, fat, and protein of the PC is shown in Table 2. The

Table 4. Mean squares ( $P$-values in parentheses) for texture profile analysis (TPA) hardness and dynamic stress rheometer (DSR) melt temperature of the process cheese

\begin{tabular}{lccc}
\hline Factor & df & $\begin{array}{c}\text { TPA } \\
\text { hardness }\end{array}$ & $\begin{array}{c}\text { DSR melt } \\
\text { temperature }\end{array}$ \\
\hline Replicate & 2 & $652,486.000$ & 38.370 \\
& & $(0.3100)$ & $(0.4300)$ \\
Treatment & 2 & $35,345,914.000$ & 29.150 \\
& & $(0.0001)$ & $(0.5200)$ \\
Error & 22 & $522,589.250$ & 43.936 \\
\hline
\end{tabular}

Table 5. Mean functionality of process cheese made with addition of 0,2 , or $4 \%$ xylitol determined by texture profile analyzer (TPA) and dynamic stress rheometry (DSR)

\begin{tabular}{|c|c|c|c|}
\hline \multirow[b]{2}{*}{ Functional property } & \multicolumn{3}{|c|}{ Xylitol } \\
\hline & $\begin{array}{c}0 \% \\
\text { (Control) }\end{array}$ & $2 \%$ & $4 \%$ \\
\hline TPA hardness (g) & $11,757.7^{\mathrm{a}}$ & $9,167.1^{\mathrm{b}}$ & $7,864.6^{\mathrm{c}}$ \\
\hline DSR melt temperature $\left({ }^{\circ} \mathrm{C}\right)$ & $71.8^{\mathrm{a}}$ & $68.8^{\mathrm{a}}$ & $68.6^{\mathrm{a}}$ \\
\hline
\end{tabular}

${ }^{\mathrm{a}-\mathrm{c}}$ Means within a row not sharing a common superscript are significantly different $(P<0.05)$.

replicate factor was not significant $(P>0.05)$ for any parameter. Additionally, we observed no significant differences $(P>0.05)$ in $\mathrm{pH}$, fat, or protein for the treatment factor. However, we did observe a significant $(P<0.05)$ difference in moisture.

Mean compositional analysis for each treatment is shown in Table 3. The $\mathrm{pH}$ of all treatments was lower than the $\mathrm{pH}$ range of typical full-fat $\mathrm{PC}$, which ranges from 5.4 to 5.8 (Kapoor and Metzger, 2008). However, in preliminary research, we determined that it was possible to have a lower $\mathrm{pH}$ in low-fat PC. This may be a result of the elevated protein content of low-fat PC.

A significant $(P<0.05)$ difference was found between the moisture content of the $0 \%$ xylitol (control) and the $4 \%$ xylitol treatment. However, moisture contents did not differ between the $0 \%$ xylitol (control) and $2 \%$ xylitol treatment or between the $2 \%$ and $4 \%$ xylitol treatments. The significantly higher moisture content of the $0 \%$ xylitol (control) treatment compared with $4 \%$ xylitol PC should improve the functional properties of the $0 \%$ xylitol (control) because additional moisture has been shown to improve the functional characteristics of reduced- or low-fat PC (Drake et al., 1999; Johnson et al., 2009). Consequently, any observed improvement in the functional properties of the $4 \%$ xylitol treatment would need to compensate for the lower moisture content in this treatment.

\section{Functional Properties}

The ANOVA with MS and $P$-values for TPA hardness and melt temperature of the PC from each treatment are shown in Table 4. The replicate factor was not significant $(P>0.05)$ for either parameter and the treatment factor was not significant $(P>0.05)$ for dynamic stress rheometer (DSR) melt temperature. However, the treatment factor was significant $(P<$ 0.05) for TPA hardness.

Mean values for TPA hardness and melt temperature of the PC from each treatment are shown in Table 4. The $4 \%$ xylitol PC had significantly $(P<0.05)$ less 


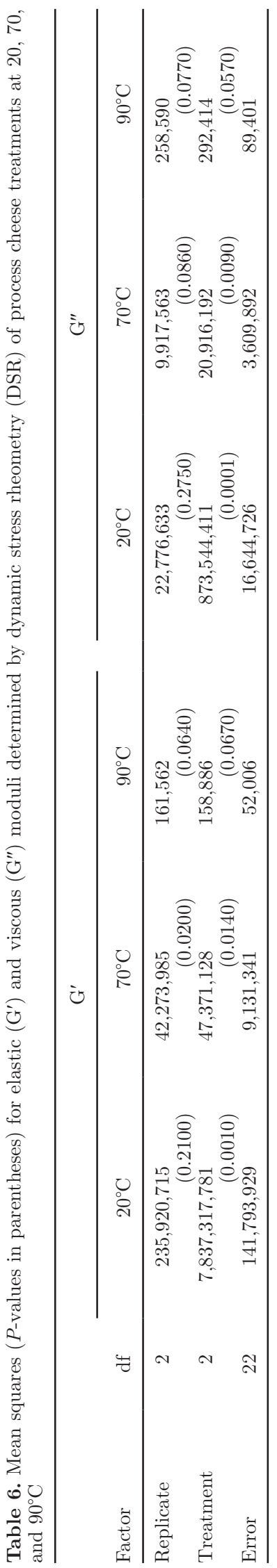

Table 7. Mean elastic $\left(\mathrm{G}^{\prime}, \mathrm{Pa}\right)$ modulus of process cheese made with addition of 0,2 , or $4 \%$ xylitol during heating from 20 to $90^{\circ} \mathrm{C}$

\begin{tabular}{lrrr}
\hline & \multicolumn{3}{c}{ Xylitol } \\
\cline { 2 - 4 } $\begin{array}{l}\text { Temperature } \\
\left({ }^{\circ} \mathrm{C}\right)\end{array}$ & $\begin{array}{c}0 \% \\
(\text { Control })\end{array}$ & $2 \%$ & $4 \%$ \\
\hline 20 & $123,114^{\mathrm{a}}$ & $81,109^{\mathrm{b}}$ & $66,208^{\mathrm{c}}$ \\
30 & $101,430^{\mathrm{a}}$ & $67,482^{\mathrm{b}}$ & $57,559^{\mathrm{b}}$ \\
40 & $65,027^{\mathrm{a}}$ & $43,698^{\mathrm{b}}$ & $36,922^{\mathrm{b}}$ \\
50 & $36,259^{\mathrm{a}}$ & $23,389^{\mathrm{b}}$ & $19,229^{\mathrm{b}}$ \\
60 & $16,069^{\mathrm{a}}$ & $9,312^{\mathrm{b}}$ & $9,469^{\mathrm{ab}}$ \\
70 & $7,473^{\mathrm{a}}$ & $3,496^{\mathrm{b}}$ & $3,503^{\mathrm{ab}}$ \\
80 & $1,931^{\mathrm{a}}$ & $1,100^{\mathrm{b}}$ & $643^{\mathrm{ab}}$ \\
90 & $530^{\mathrm{a}}$ & $409^{\mathrm{a}}$ & $264^{\mathrm{a}}$ \\
\hline
\end{tabular}

${ }^{\mathrm{a}-\mathrm{c}}$ Means within a row not sharing a common superscript are significantly different $(P<0.05)$.

hardness than the $2 \%$ and $0 \%$ xylitol PC, and the $2 \%$ xylitol had significantly $(P<0.05)$ less hardness than the $0 \%$ xylitol PC (Table 5). The reduction in TPA hardness was substantial and was 22 and $33 \%$, respectively, for the 2 and $4 \%$ xylitol treatments compared with the $0 \%$ xylitol (control). A similar improvement in the texture of low-fat cookies containing xylitol was reported by Zoulis and Piknis (2000). The lower TPA values substantiate the proposed lubrication effect of xylitol within the protein matrix of PC. Rheological studies conducted by Drake et al. (1999) reported a similar reduction in the TPA hardness of $50 \%$ reducedfat PC containing lecithin as a fat replacer. A small but not significant $(P>0.05)$ difference occurred in the melt temperature values as the xylitol content increased. These results indicate that xylitol addition had no effect on the melt temperature of low-fat PC. Similar to this study, Hassan et al. (2007) reported that in $35 \%$ reduced-fat PC produced from reduced-fat Cheddar cheese made with EPS-producing starter cultures did not affect the melt temperature of reduced-fat PC.

Table 8. Mean viscous (G", Pa) modulus of process cheese made with addition of 0,2 , or $4 \%$ xylitol during heating from 20 to $90^{\circ} \mathrm{C}$

\begin{tabular}{lrrr}
\hline & \multicolumn{3}{c}{ Xylitol } \\
\cline { 2 - 4 } $\begin{array}{l}\text { Temperature } \\
\left({ }^{\circ} \mathrm{C}\right)\end{array}$ & $\begin{array}{c}0 \% \\
(\text { Control })\end{array}$ & $2 \%$ & $4 \%$ \\
\hline 20 & $41,539^{\mathrm{a}}$ & $26,968^{\mathrm{b}}$ & $22,767^{\mathrm{b}}$ \\
30 & $36,181^{\mathrm{a}}$ & $23,709^{\mathrm{b}}$ & $21,473^{\mathrm{b}}$ \\
40 & $26,236^{\mathrm{a}}$ & $17,533^{\mathrm{b}}$ & $16,241^{\mathrm{b}}$ \\
50 & $17,768^{\mathrm{a}}$ & $11,744^{\mathrm{b}}$ & $11,045^{\mathrm{b}}$ \\
60 & $10,608^{\mathrm{a}}$ & $6,650^{\mathrm{b}}$ & $6,580^{\mathrm{b}}$ \\
70 & $5,926^{\mathrm{a}}$ & $3,337^{\mathrm{b}}$ & $3,237^{\mathrm{b}}$ \\
80 & $2,142^{\mathrm{a}}$ & $1,541^{\mathrm{b}}$ & $1,042^{\mathrm{b}}$ \\
90 & $943^{\mathrm{a}}$ & $852^{\mathrm{a}}$ & $596^{\mathrm{a}}$ \\
\hline
\end{tabular}

$\overline{\mathrm{a}, \mathrm{b}}$ Means within a row not sharing a common superscript are significantly different $(P<0.05)$. 


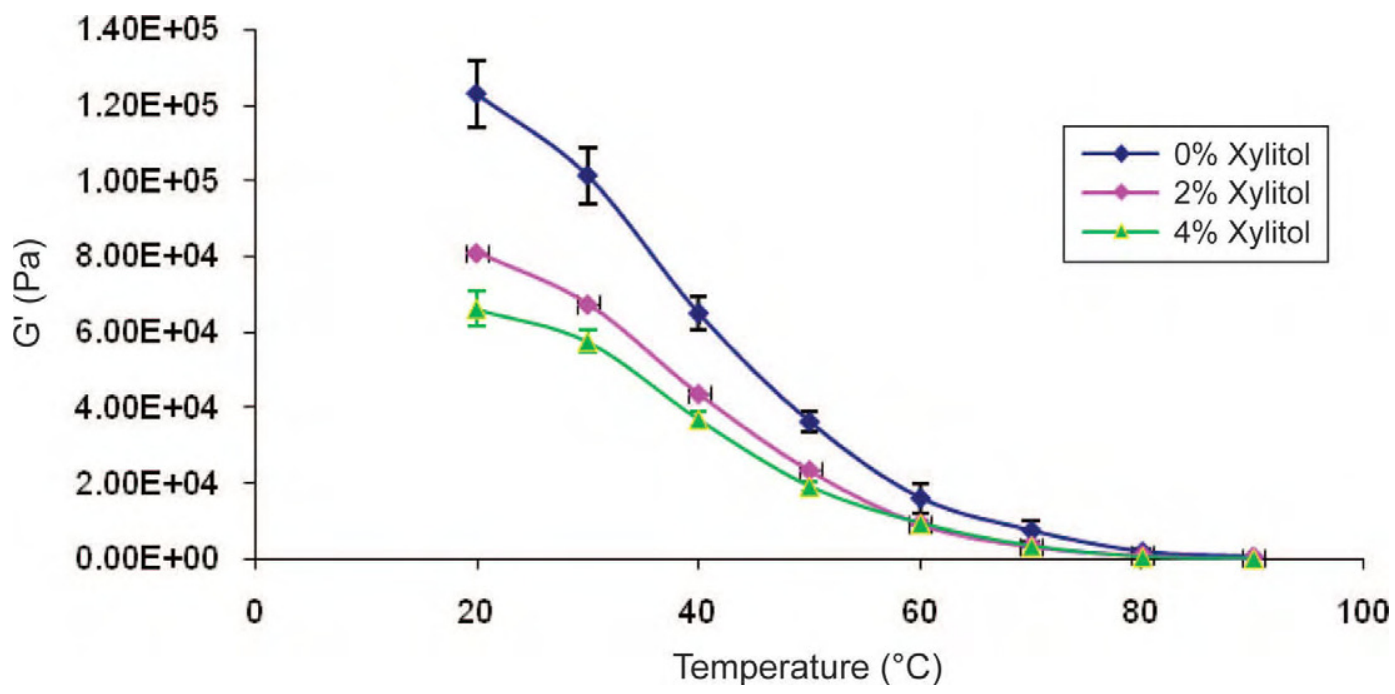

Figure 1. Elastic $\left(\mathrm{G}^{\prime}, \mathrm{Pa}\right)$ modulus of process cheese, made with addition of 0,2 , or $4 \%$ xylitol, during heating from 20 to $90^{\circ} \mathrm{C}$ at the rate of $1^{\circ} \mathrm{C} /$ min during dynamic rheological analysis. Color version available in the online PDF.

The ANOVA table with MS and $P$-values at 20, 70, and $90^{\circ} \mathrm{C}$ for both elastic $\left(\mathrm{G}^{\prime}, \mathrm{Pa}\right)$ and viscous $\left(\mathrm{G}^{\prime \prime}\right.$, $\mathrm{Pa})$ moduli of the $\mathrm{PC}$ from each treatment are shown in Table 6 . The mean values for $\mathrm{G}^{\prime}$ of the $\mathrm{PC}$ during heating from 20 to $90^{\circ} \mathrm{C}$ at $10^{\circ} \mathrm{C}$ increments for each treatment are shown in Table 7, and those for $\mathrm{G}^{\prime \prime}$ are shown in Table 8 . Figures 1 and 2 graphically show the effects of the 0,2 , and $4 \%$ xylitol content on $\mathrm{G}^{\prime}$ and $\mathrm{G}^{\prime \prime}$, respectively, on $\mathrm{PC}$ during heating from 20 to $90^{\circ} \mathrm{C}$.

The $\mathrm{G}^{\prime}$ and $\mathrm{G}^{\prime \prime}$ of the $2 \%$ and $4 \%$ xylitol treatments were lower than that of the $0 \%$ xylitol (control) be- tween 20 and $70^{\circ} \mathrm{C}$ (Figures 1 and 2). These differences were significant $(P<0.05)$ between 20 and $50^{\circ} \mathrm{C}$ for $\mathrm{G}^{\prime}$ (Table 7) and between 20 and $70^{\circ} \mathrm{C}$ for $\mathrm{G}^{\prime \prime}$ (Table 8 ). The comparison between the $2 \%$ and $4 \%$ xylitol treatments showed that $\mathrm{G}^{\prime}$ was significantly different at $20^{\circ} \mathrm{C}$, but no significant $(P>0.05)$ differences were found at any temperature for $\mathrm{G}^{\prime \prime}$. These results clearly demonstrate that xylitol has a substantial effect on the rheological characteristics of low-fat PC.

A study by Subramanian et al. (2006) on the viscoelastic properties of regular and $80 \%$ reduced-fat PC

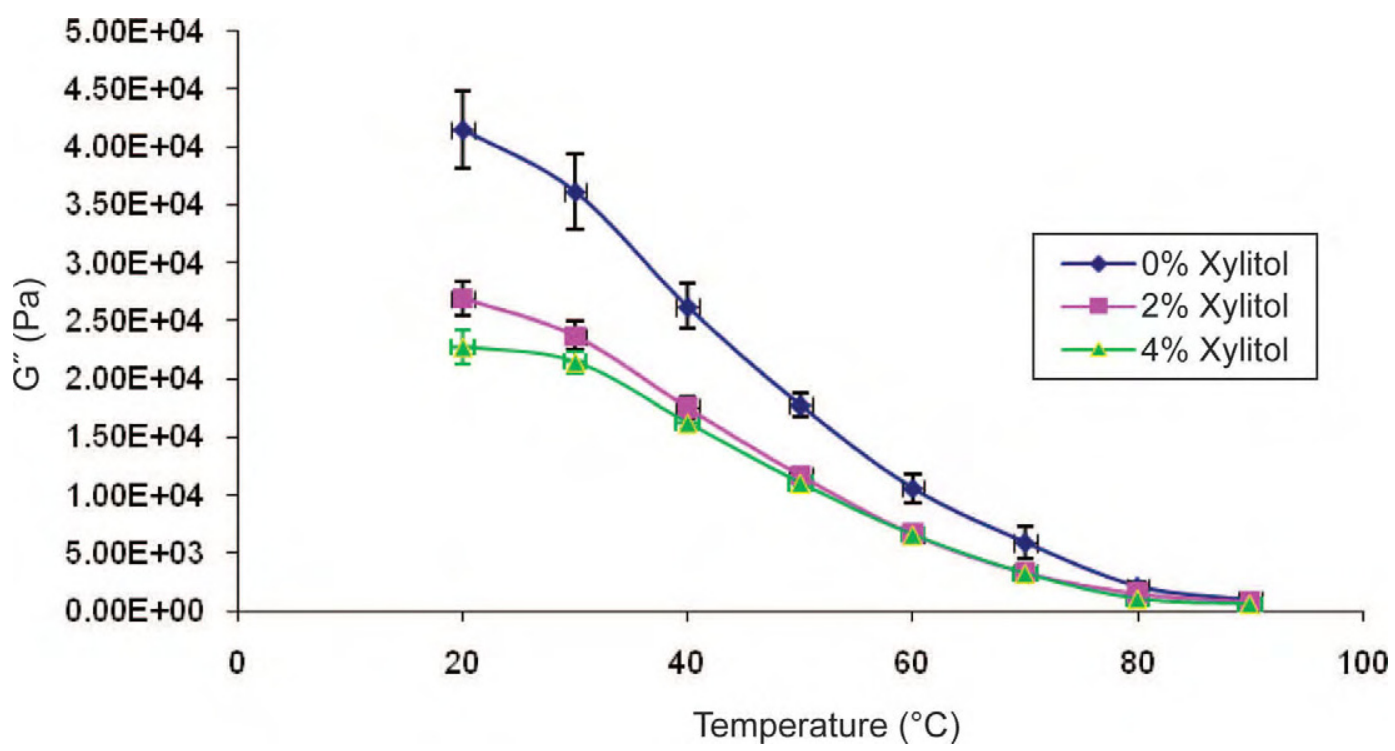

Figure 2. Viscous (G", Pa) modulus of process cheese, made with addition of 0,2 , or $4 \%$ xylitol, during heating from 20 to $90^{\circ} \mathrm{C}$ at the rate of $1^{\circ} \mathrm{C} /$ min during dynamic rheological analysis. Color version available in the online PDF. 
(4.76\% fat) reported higher dynamic viscosity values for $80 \%$ reduced-fat PC. The current study demonstrates that the high dynamic viscous values typically observed in reduced- or low-fat PC can be reduced by 40 to $50 \%$ with the addition of $4 \%$ xylitol. The improvement in the functional characteristics of xylitol-containing lowfat PC may be a result of lubrication within the protein matrix caused by xylitol. The results also indicate that the lubrication effect of xylitol is more substantial at lower temperatures $\left(<20^{\circ} \mathrm{C}\right)$ and becomes less critical as the protein matrix collapses during melting $\left(>70^{\circ} \mathrm{C}\right)$.

\section{CONCLUSIONS}

Compositional analysis showed no significant difference between treatments except for the significantly lower moisture content of the $4 \%$ xylitol treatment compared with the control ( $0 \%$ xylitol). Even with significantly lower moisture content, addition of $4 \%$ xylitol improved the functional characteristics of low-fat PC. Results of TPA showed a significant decrease in hardness with an increase in xylitol content. Melt temperature obtained with DSR did not differ significantly among the treatments. The $\mathrm{G}^{\prime}$ and $\mathrm{G}^{\prime \prime}$ values indicated only slight differences between 2 and $4 \%$ xylitol treatments, but these 2 treatments were significantly different from the $0 \%$ xylitol treatment (control) in the heating range of 20 to $80^{\circ} \mathrm{C}$. Overall, compositional and functional analyses indicated that xylitol-containing PC samples have improved functional properties. Consequently, xylitol could be used as a fat replacer to improve the functional properties of low-fat PC.

\section{ACKNOWLEDGMENTS}

We thank the Midwest Dairy Association (St. Paul, $\mathrm{MN}$ ), and Dairy Management Inc. (Rosemont, IL), as administered by Dairy Research Institute, for their financial support.

\section{REFERENCES}

Atherton, H. V., and J. A. Newlander. 1977. Tests for fat: Babcock, Gerber, and Mojonnier. Pages 71-116 in Chemistry and Testing of Dairy Products. 4th ed. AVI Publ. Co. Inc., Westport, CT.

Brummel, S. E., and K. Lee. 1990. Soluble hydrocolloids enable fat reduction in process cheese spreads. J. Food Sci. 55:1290-1292. 1307.

Caric, M., and M. Kalab. 1993. Processed cheese products. Pages 467505 in Cheese: Chemistry, Physics and Microbiology. Vol. 2. 2nd ed. P. F. Fox, ed. Chapman and Hall, London, UK.

Davison, B. C., W. H. Schwimmer, L. J. Prostko, A. C. Hamann, G. S. Buliga, A. A. Heth, L. K. Jackson, P. J. Kerwin, M. S. Miller, D. G. Pechak, and G. F. Smith, inventors. 1993. Low fat processed cheese product having fat-mimetic properties and method of making same. Assignee: Kraft General Foods Inc. US Patent No. 5215778.

Drake, M. A., V. D. Truong, and C. R. Daubert. 1999. Rheological and sensory properties of reduced-fat processed cheeses containing lecithin. J. Food Sci. 64:744-747.

Food and Drug Administration. 2008a. 21CFR.133.169-133.180: Cheese and related cheese products. Food and Drug Administration, Department of Health and Human Services, Washington, DC

Food and Drug Administration. 2008b. 21CFR130.10: Requirement for foods named by use of a nutrient content claim and a standardized term. Food and Drug Administration, Department of Health and Human Services, Washington, DC.

Food and Drug Administration. 2008c. 21CFR101.62: Nutrient content claim for fat, fatty acid, and cholesterol content of foods. Food and Drug Administration, Department of Health and Human Services, Washington, DC.

Gwartney, E. A., E. A. Foegeding, and D. K. Larick. 2002. The texture of commercial full fat and reduced fat cheese. J. Food Sci $67: 2173-2183$

Hassan, A. N., S. Awad, and V. V. Mistry. 2007. Reduced fat process cheese made from young reduced fat cheddar cheese manufactured with exopolysaccharide-producing cultures. J. Dairy Sci. 90:3604-3612.

Johnson, M. E., R. Kapoor, D. J. McMahon, D. R. McCoy, and R. G. Narasimmon. 2009. Reduction of sodium and fat levels in natural and processed cheeses: Scientific and technological aspects. Comp. Rev Food Sci. Food Safety 8:252-268.

Jones, S. A. 1996. Issues in fat replacement. Pages 3-26 in Handbook of Fat Replacers. S. Roller and S. A. Jones, ed. CRC Press, Boca Raton, FL.

Kapoor, R., and L. E. Metzger. 2008. Process cheese: Scientific and technological aspects - A review. Comp. Rev. Food Sci. Food Safety $7: 194-214$.

Lee, S. K., R. J. Buwalda, S. R. Euston, E. A. Foegeding, and A. B. McKenna. 2003. Changes in the rheology and microstructure of processed cheese during cooking. Lebenson. Wiss. Technol. 36:339-345

McMahon, D. J., M. C. Alleyene, R. L. Fife, and C. J. Oberg. 1996 Use of fat replacers in Mozzarella cheese. J. Dairy Sci. 79:19111921.

Mehnert, D. W., and S. Prince, inventors. 1996. Methods and composition for fat free process cheese. Assignee: Kraft Foods Inc. US Patent No. 5585132.

Metzger, L. E. 2003. Nutritional labelling using a computer program. Pages 1-6 in Food Analysis Laboratory Manual. S. S. Nelson, ed. Kluwer Academic, New York, NY.

Meyer, A. 1973. Processed Cheese Manufacture. Food Trade Press Ltd., London, UK.

Muir, D. D., S. A. R. Williams, A. Y. Tamime, and M. E. Shenana 1997. Comparison of the sensory profiles of regular and reducedfat commercial processed cheese spreads. Int. J. Food. Sci. Tech. (Paris) 32:279-287.

Musthaq, Z., Shakeel-ur-Rehman, T. Zahoor, and A. Jamil. 2010 Impact of xylitol replacement on physicochemical, sensory and microbial quality of cookies. Pak. J. Nutr. 9:605-610.

Napier, K. 1997. Fat replacers-The cutting edge of cutting calories. A report. American Council on Science and Health, New York, NY.

Prentice, J. H. 1987. Cheese rheology. Pages 299-344 in Cheese: Chemistry, Physics, and Microbiology, P.F. Fox, ed. Elsevier Science Publishing Company Inc., New York, NY.

Price, K. M. 2007. Microstructure and functionality of processed cheese: The role of milk fat. MS Thesis. Graduate Faculty of North Carolina State University, Raleigh. http://repository.lib.ncsu.edu/ ir/bitstream/1840.16/260/1/etd.pdf.

Raval, D. M., and V. V. Mistry. 1999. Application of ultra-filtered sweet buttermilk in the manufacture of reduced fat process cheese. J. Dairy Sci. 82:2334-2343

Sandrou, D. K., and I. S. Arvanitoyannis. 2000. Low-fat/calorie foods: Current state and perspectives. Crit. Rev. Food Sci. Nutr. 40:427-447. 
Sorensen, H. H. 2001. The world market for cheese. 5th ed. IDF Bull. $359: 4-62$.

Subramanian, R., K. Muthukumarappan, and S. Gunasekaran. 2006. Linear viscoelastic properties of regular- and reduced-fat pasteurized process cheese during heating and cooling. Int. J. Food Prop. 9:377-393.

Sutheerawattananonda, M., and E. D. Bastian. 1998. Monitoring process cheese meltability using dynamic stress rheometry. J. Texture Stud. 29:169-183.

Swenson, B. J., W. L. Wendorff, and R. C. Lindsay. 2000. Effects of ingredients on the functionality of fat-free process cheese spreads. J. Food Sci. 65:822-825.
Thomas, M. A. 1973. The manufacture of processed cheese - Scientific principles. 1st ed. New South Wales Department of Agriculture, Richmond, NSW, Australia.

Tomasik, P. 2003. Chemical and Functional Properties of Food Saccharides. CRC Press, Boca Raton, FL.

Zhong, Q. 2003. Cooling effects on the functionality and microstructure of processed cheese. PhD Diss. North Carolina State University, Raleigh.

Zoulias, E. I., and S. Piknis. 2000. Effect of sugar replacement by polyols and acesulfame-K on properties of low-fat cookies. J. Sci. Food Agric. 80:2049-2056. 